\title{
MITOS LORELEI DARI WAKTU KE WAKTU: KAJIAN FEMINISME EKSISTENSIALISME PADA TIGA LIRIK LORELEI TAHUN 1823, 1981, DAN 2013
}

\author{
Griselda Febrina Talitha \\ Universitas Indonesia \\ email: griseldagege@ui.ac.id \\ Lisda Liyanti \\ Universitas Indonesia \\ email: lisda.liyanti31@ui.ac.id
}

\begin{abstract}
This study analised the theme of the myth reflected in three lyrics of Lorelei from three different times. Lorelei is a mythical woman whose name is taken from a cliff on the Rhine. This research will refer to the relationship between women (Lorelei) and male figures and the relation will be analyzed through the perspective of existentialist feminism using two main concepts, men as Subjects and women as the Others. This study chose the Lorelei-lyrics from three different time, Heinrich Heine's Lorelei (1823), Dschinghis Khan's Loreley (1981), and Faun's Lore Lay (2013) to show the Lorelei myth displayed in different era. Having studied the existentialism feminism, it can be seen that Lorelei is still described as the object which is marginalized by the strong myth of the fame fatale. The depictions of Lorelei's subjectivity can be found in some parts of the lyrics by Dchingis Khan (1981) and Faun (2013), but those depictions are still very vague.
\end{abstract}

Keywords: myth, existentialism feminism, men, women

\begin{abstract}
ABSTRAK
Penelitian ini mengangkat tema mengenai mitos yang terkandung di dalam tiga buah lirik mengenai Lorelei dari tiga masa berbeda. Lorelei adalah mitos perempuan yang namanya diambil dari sebuah tebing di atas sungai Rhein. Penelitian mengacu kepada relasi antara perempuan (Lorelei) dengan tokoh laki-laki. Relasi tersebut akan dianalisis melalui perspektif feminisme eksistensialis menggunakan dua konsep utama, yaitu laki-laki sebagai Subjek dan perempuan sebagai Sang Liyan. Penelitian ini memilih lirik Lorelei dari tiga rentang waktu yang berbeda, yaitu Lorelei karya Heinrich Heine yang diciptakan pada tahun 1823, Loreley karya Dschinghis Khan yang diciptakan pada tahun 1981, dan Lore Lay karya Faun yang diciptakan pada tahun 2013 untuk menampilkan mitos Lorelei ditampilkan dari waktu ke waktu. Melalui telaah feminisme eksistensialisme, sebagian besar bait Lorelei mengambarkan perempuan sebagai posisi objek yang termarjinalkan dengan mitos fame fatale. Penggambaran subjektivitas Lorelei dapat ditemukan pada beberapa bagian lirik karya Dchingis Khan dan Faun, namun masih sangat samar.
\end{abstract}

Kata kunci: mitos, feminisme eksistensialisme, laki-laki, perempuan 


\section{PENDAHULUAN}

Awal mula kemunculannya, gerakan feminisme dilatarbelakangi oleh ketidakadilan yang dirasakan oleh kaum perempuan. Ketidakadilan yang dialami perempuan termanifestasikan ke dalam berbagai aspek, baik aspek politis, keagamaan, dan sosial. Dari aspek politis misalnya, perempuan Amerika merasa diabaikan dalam teks deklarasi kemerdekaan (Gemberling, 2014). Aspek keagamaan tercermin dalam sikap gereja yang kerap memandang kedudukan perempuan lebih rendah derajatnya dibandingkan dengan laki-laki. Sementara, aspek sosial terlihat dari anggapan marjinal terhadap perempuan dengan tugas-tugasnya yang seringkali berhubungan dengan tugas domestik (Djajanegara, 2000, hlm. 1-3). Tidak hanya itu saja, bentuk subordinasi terhadap perempuan juga dijumpai dalam karya sastra (Diana, 2018). Dalam sejarah perkembangan kesusastraan, laki-laki lebih banyak menghasilkan karya sastra dibandingkan perempuan. Karya-karya mereka juga menjadi bacaan wajib, khususnya di ruang lingkup akademis (Djajanegara, 2010: 38). Karya sastra ciptaan laki-laki juga kerap kali menampilkan perempuan yang dikonstruksikan sebagai sosok yang tidak berdaya, pasif, dan sulit menentukan pilihan hidup. Selain itu, penulis laki-laki juga cenderung berfokus pada peran-peran tradisional yang khas perempuan, seperti istri yang patuh, ibu rumah tangga yang baik, bahkan juga objek seks semata (Djajanegara, 2000: 50).

Konstruksi-konstruksi tersebut juga diaplikasikan pada mitos yang terdapat dalam masyarakat. Salah satu contohnya adalah dongeng klasik berjudul The Little Mermaid. Dongeng tersebut diciptakan oleh Hans Christian Andersen dan menceritakan mengenai tokoh putri duyung yang jatuh hati kepada seorang pangeran. Bahkan, sang tokoh rela memberikan suaranya demi sepasang kaki supaya dapat bersama dengan sang pangeran di daratan. Namun malang baginya, sang pangeran tidak membalas perasaannya dan justru menikahi perempuan lain. Sang putri duyung yang patah hati kemudian bunuh diri dan berubah menjadi buih di langit (Tseelon, 1995: 3-4).

Contoh mitos lain yang mengandung unsur subordinasi kaum perempuan juga dapat dilihat pada karya sastra mengenai legenda Lorelei. Lorelei sebenarnya merupakan nama dari sebuah tebing batu yang terdapat di atas sungai Rhein. Tebing tersebut dianggap membahayakan karena mempunyai lebar sebesar 113 meter dengan kedalaman sepanjang dua puluh lima meter. Tempat tersebut menginformasikan berbagai kejadian tragis, seperti kapal yang tenggelam. Hal ini yang membuat Clemens Brentano, sastrawan asal Jerman, menjadi terinspirasi untuk membuat sebuah balada berjudul Bacharach am Rheine. Balada karya Brentano tidak membahas tebing sama sekali, melainkan hanya menyebutkan seorang 
perempuan dengan kemampuan melebihi manusia yang berasal dari Desa Bacharah dan kerap kali mengumbar pesona yang dimilikinya (Olze, 2013).

Setelah balada karya Brentano diterbitkan, beberapa karya serupa juga muncul dan diilhami dari balada ciptaannya. Salah satunya adalah puisi yang berjudul Lorelei yang dibuat oleh Heinrich Heine pada tahun 1823. Puisi ini menceritakan mengenai sosok perempuan cantik bernama Lorelei yang memiliki rambut panjang berwarna kuning keemasan. Sosoknya digambarkan sedang duduk anggun di atas tebing batu sambil kerap kali menyisir rambutnya dengan sisir emas. Lorelei juga diceritakan memiliki suara yang begitu memabukkan dan menawan hati, sehingga membuat siapapun yang mendengarnya menjadi terlena dan pada akhirnya tenggelam.

Meskipun kisah antara The Little Mermaid dan Lorelei memiliki kandungan cerita yang bertolak belakang, penggunaan elemen suara perempuan menjadi hal yang utama dalam pokok atau motif. Lorelei menggunakan suaranya untuk menguasai dan membuat laki-laki terbuai. The Little Mermaid kehilangan suaranya akibat laki-laki. Namun, keduanya sama-sama memiliki kesamaan. Indikasi penindasan dan penggambaran perempuan sebagai sosok yang lain juga dimunculkan. Fakta ini menunjukkan bahwa representasi perempuan dari sisi feminis menjadi hal yang menarik untuk dilihat dalam teks Lorelei.

Penelitian mengenai Lorelei sudah pernah dilakukan oleh Nandi Wardhana Manggala Aryaguna (2012). Penelitin ini hanya berfokus kepada satu zaman saja, yaitu zaman Romantik dan memakai pendekatan atau sudut pandang yang bersifat patriarki. Hal ini menunjukkan bahwa sudut pandang feminis masih diabaikan dan cenderung tidak diperhatikan. Penelitian sebelumnya beranggapan bahwa sosok Lorelei dalam puisi bersifat merugikan. Sehubungan dengan hal tersebut, penelitian ini kembali mengulasnya, membaca, atau menginterpretasikan perspektif yang berbeda. Pendekatan yang berperspektif feminisme eksistensialisme menjadi fokus untuk melihat citra karakter dari teks itu sebagai representasi pada masanya.

Penelitian ini bertujuan ingin melihat tidak hanya melihat dan berpegang pada Masa Romantik saja, tetapi mewakili tiga rentang waktu yang berbeda atau tiga masa berbeda. Sebagai korpus data, penelitian ini memilih lirik Lorelei karya Heinrich Heine tahun 1823, lirik Loreley karya Dschinghis Khan tahun 1981, dan musikalisasi lirik Lore Lay karya Faun tahun 2013. Hal yang hendak dicari adalah representasi dari ketiga teks itu dalam membangun atau menampilkan sosok perempuan atau isu-isu identitas perempuan dalam tiga masa melalui tiga karya tersebut. Dari ketiga karya tersebut, perbedaan atas cara pandang terhadap isu 
identitas atau representasi perempuan akan terlihat sebagai cara pandang zaman atas perempuan.

\section{TEORI DAN METODE PENILITIAN}

Secara harafiah, kata feminisme didefinisikan sebagai gerakan wanita yang menuntut persamaan hak sepenuhnya antara kaum wanita dan pria. Pergerakan feminisme terbagi ke dalam beberapa aliran. Aliran pertama dimulai sejak tahun 1800. Awalnya, kaum feminis pada masa itu menuntut persamaan hak atas kedudukannya yang inferior, khususnya pada bidang hukum, ekonomi, dan sosial. Kesamaan hak dalam hal perkawinan, pembagian harta yang sama rata, serta persamaan pendidikan menjadi fokus utama yang dikejar oleh perempuan. Selain itu, perempuan juga menghendaki kesetaraan dalam aspek politik, khususnya pada hak memilih dan dipilih. Hal ini menyebabkan adanya peningkatan dalam bidang pendidikan yang ditandai dengan adanya sejumlah perguruan tinggi yang dikhususkan untuk perempuan (Djajanegara, 2010: 6-8).

Salah satu tokoh penting dalam gerakan feminis adalah Mary Stone Wollstonecraft. Dia terkenal dengan tulisan yang berjudul A Vindication of the Rights of Woman, pada tahun 1792. Beberapa abad kemudian, tokoh lain seperti Virginia Woolf muncul dengan tulisan yang berjudul A Room of One"s Own. Fokus utama atau pikiran yang dibawa pada aliran ini adalah penggunaan akal secara maksimum. Hal itu hanya dapat didapatkan dengan cara memperoleh pendidikan. Oleh karena itu, pendidikan wajib diberikan bukan hanya kepada laki-laki, tetapi kepada perempuan. Hal ini bertujuan agar perempuan dapat mengembangkan kemampuan sebagai manusia yang utuh (Tong, 1989: 21).

Kemunculan karya Betty Friedan, The Feminine Mystique (1963), menandai aliran pergerakan feminisme yang kedua. Pada aliran ini, kaum feminis memperjuangkan hak berupa seksualitas perempuan, penghapusan diskriminasi seksual, dan penyamarataan pembagian tugas-tugas rumah tangga. Dampak dari hal itu terlihat dari posisi laki-laki yang mulai terlihat di dapur dan perempuan yang mampu menjadi tentara. Namun, hal ini juga memiliki dampak negatif, seperti jumlah kasus perceraian yang meningkat dan banyak perempuan yang memilih untuk menjadi orang tua tunggal (Djajanegara, 2010: 10-11).

Contoh dari aliran kedua adalah feminisme eksistensialisme, yang dikenal dari pemikiran Simone de Beauvoir. Karya Beauvoir, The Second Sex (1949), menjadi ikon dari aliran ini. Setelah gelombang kedua, selanjutnya, feminisme gelombang ketiga muncul pada tahun 1900. Pada gelombang ketiga, kaum yang disebut dengan kaum anti-esensialisme menganggap ada perbedaan antara peristiwa yang dialami 
para perempuan. Penyebab dari hal itu adalah latar belakang perempuan dan pengalaman perempuan yang berbeda-beda. Oleh karena itu, pergerakan feminisme gelombang ketiga memusatkan perhatian pada keberagaman ras, etnis, dan warna kulit (Stone, 2004). Tokoh-tokoh yang berperan dalam feminisme gelombang ketiga adalah Julia Kristeva dan Luce Irigaray.

Menurut Dagun (1990: 17), eksistensialisme adalah salah satu jenis cabang filsafat yang memandang segalanya berlandaskan pada eksistensi manusia. Manusia menciptakan dirinya secara aktif dan mengukuhkan eksistensinya. Eksistensi di sini dapat diartiakn sebagai berbuat, menjadi, dan merencanakan (Dagun, 1990). Salah satu filsuf yang berperan penting adalah Jean Paul Sartre. Menurutnya, manusia merupakan makhluk yang mendahulukan eksistensi daripada esensi. Oleh karena itu, manusia berbeda dengan makhluk lainnya.

Sesuai dengan konsep yang dikemukakan Sartre mengenai manusia ada yang ada begitu saja, ada sendiri dibagi dalam bentuk ada untuk dirinya sendiri dan ada untuk orang lain (Bertens, 1987:85). Ketiga konsep ini kemudian digunakan oleh Simone de Beauvoir yang merupakan seorang feminis, dalam bukunya The Second Sex (1949). Beauvoir berargumen bahwa perempuan yang selalu disubjektifikasi oleh laki-laki. Perempuan tidak lebih dari sesuatu yang dikatakan oleh laki-laki tentangnya. Oleh karena itu, perempuan disebut sebagai "seks". Pendefinisian perempuan berbeda dengan laki-laki yang dianggap sebagai subjek absolut. Dia dijabarkan tercipta secara kebetulan. Oleh karena itu, laki-laki dipandang sebagai sang Subjek. Sebaliknya, perempuan adalah Sang Lain (Beauvoir, 1956: xii)

Jenis penelitian dalam tulisan ini adalah penelitian kualitatif. Seperti yang diungkapkan, masalah atau tujuan utama dari penelitian adalah melihat representasi identitas perempuan atau citra perempuan dari ketiga teks yang mewakili zaman yang berbeda. Objek material dari tulisan ini adalah ketiga teks tersebut. Objek formal dari tulisan ini adalah konsep perempuan yang ditawarkan oleh teks tersebut. Data dari penelitian ini adalah tulisan, kata-kata, isi karya, dan konsep perempuan yang terrepresentasi dalam teks tersebut. Teknik interpretasi data dilakukan dengan melakukan pembacaan hermenutik atas representasi perempuan dengan prespektif feminis.

\section{HASIL DAN PEMBAHASAN}

\section{Perempuan yang Dikuasai dalam Lorelei karya Heinrich Heine}

Puisi yang memiliki bentuk lirik ini diciptakan oleh Heinrich Heine pada tahun 1823. Lirik ini terdiri dari enam bait. Setiap baitnya terdiri dari empat larik. 
Lirik ini menggunakan sudut pandang orang pertama, das lyrische Ich pada keseluruhan lirik ini. Melalui das lyrische Ich, tokoh Ich menjadi subjek hidup sekaligus saksi di dalam suatu lirik. Selain itu, Ich di sini juga memiliki fungsi sebagai pencerita (Erzähler). Sebagian besar pengarang tidak berperspektif IchErzähler. Mereka menempatkan dirinya pada karya sastra. Oleh karena itu, istilah Sprecherinstanz (juru bicara) juga ditemukan. Tokoh Ich yang dipaparkan oleh pengarang bersifat netral secara keseluruhan (Esser, 2007: 50). Heine disini hanya bertindak sebagai Sprecherinstanz tanpa melibatkan dirinya sendiri ke dalam lirik. Penggunaan das lyrische Ich pada lirik ini dapat dilihat pada kutipan bait "Ich glaube die Wellen verschlingen" (aku rasa, gelombang menelan). Penggunaan Specherinstanz yang tidak terlibat dalam kegiatan tersebut memberikan kesan berjarak dalam menceritakan sebuah kisah dalam lirik ini.

Lirik Lorelei versi Heine memiliki dua tokoh, yaitu tokoh Lorelei dan sang Nakhoda ("den Schiffer"). Relasi antara keduanya terbagi ke dalam dua posisi Subjek-Objek. Penggambaran laki laki sebagai subjek dapat dilihat dari penggambaran sikap nakhoda saat mendengar Lorelei bernyanyi, yaitu pada kalimat "ergreift es mit wildem Weh" (sang Nakhoda menyambut lagunya dengan hasrat yang liar). Aliterasi dan asonansi ${ }^{1}$ yang terdapat pada kutipan ini dipikirkan dengan matang untuk menciptakan kesan tertentu. Bunyi / $t /$ yang tergolong ke dalam suara berat ${ }^{2}$. Hal ini dimaknai untuk menekankan maskulintias dan perilaku berusaha yang terlihat melalui kata ergreift yang berarti meraih.

Sementara itu, aliterasi /w/ yang temasuk ke dalam suara melodius digunakan untuk menciptakan dan mengintensifkan keliaran hasrat. Hal ini juga berhubungan dengan mitos penciptaan. Laki-laki merupakan keturunan Adam dan memang ditakdirkan untuk mencari tulang rusuknya dalam artian pelengkap hidupnya. Pada diri perempuan, laki-laki mengisi kekurangan dalam dirinya dan berharap mencapai realisasi diri (Beauvoir, 1956: 161). Kalimat lain yang menekankan maskulinitas atas laki-laki sebagai subjek yaitu "er schaut nicht die Felsenriffe" (ia, sang Nakhoda, tidak melihat batu karang). Sesuai dengan pendapat Beauvoir bahwa kegigihan laki-laki yang memusatkan seluruh perhatian supaya tujuannya tercapai. Nyawa bukan tolak ukur terpenting bagi laki-laki dalam hal

\footnotetext{
${ }^{1}$ Aliterasi merujuk pada pengulangan bunyi konsonan, sedangkan asonansi merujuk pada pengulangan bunyi vokal (Siswantoro, 2010: 229)

${ }^{2}$ Suara berat (cacaphonus sound) merupakan suara yang berefek kasar, berat, dan tidak nyaman karena adanya hambatan dalam pelafalan. Kategori suara berat yaitu /b/, /p/, /g/, /k/, /d/, /t/. (Siswantoro, 2010: 152). Sebaliknya, suara melodius (euphonius sound) merupakan suara yang enak didengar dan mendukung makna merdu dan nyaman. Kategori suara melodius yaitu semua jenis vokal, bunyi liquid /1/, /m/, /r/, /n, bunyi lembut /f/, v/, bunyi semi vokal /w/, /y/, bunyi desis /s/, bunyi /è/ dan /wh/. (Siswantoro, 2010: 149)
} 
mencapai keinginan. Justru, hal mempertaruhkan nyawa yang menempatkan ke dalam kedudukan Subjek. (Beauvoir, 1956: 89).

Berbeda dengan penggambaran tokoh laki-laki yang digambarkan aktif menginginkan Lorelei, Lorelei sendiri digambarkan sebagai objek yang diinginkan oleh sang nakhoda. Atribut yang mendeskripsikan Lorerei memuat harapan kualitas perempuan yang dinginkan para lelaki. Pertama adalah kata "Jungfrau" (perempuan muda/perawan). Kata ini menekankan dirinya sebagai perempuan muda atau perawan. Perawan dianalogikan dengan segarnya musim semi, cahaya fajar dalam kuncup bunga, dan kilauan mutiara yang belum terpapar cahaya mentari. Keinginan laki-laki atas keperawanan dikhususkan untuk memilikinya secara mutlak (Beauvoir, 1956: 173).

Identitas keperawaan ditandai dengan citra fisik. Ketika selaput dara perempuan terkoyak, keperawanan perempuan terenggut dan tidak bisa dikembalikan. Lorelei yang digambarkan masih perawan ini menempatkan diri sebagai objek yang ingin dimiliki seutuhnya. Dia penuh hasrat oleh sang nakhoda. Selanjutnya, kata "schönste"(paling cantik). Beauvoir (1956) menyatakan bahwa terdapat tuntutan terhadap perempuan berupa kecantikan. Kecantikan yang didambakan laki-laki membuat tubuh perempuan memberikan kualifikasi objek yang lemah juga pasif (Beauvoir, 1956: 175). Dalam hal ini, kecantikan fisik yang dimilikinya kembali menempatkannya ke dalam posisi yang marjinal. Frasa "goldenes Haar" (rambut keemasan) menguatkan hal ini.

Pada teks ini, warna emas menjadi simbol sesuatu yang positif. Hal ini dikarenakan memiliki hubungan dengan daya tarik dan keagungan. Simbol rambut emas yang dimiliki melengkapi kecantikannya. Selain itu, pada frasa "goldenes Geschmeide" (perhiasan emas), penggunaan perhiasan pada perempuan menjadi penekanan atas tuntutan penampilan yang dikehendaki oleh laki-laki (Beauvoir, 1956: 176). Pada teks ini, warna emas ditafsirkan sebagai sesuatu yang positif karena hal itu berhubungan dengan daya tarik.

Dalam tulisan berjudul Color in Western Art: An Issue? (1990), Gage menjelaskan makna penting dari warna dalam suatu kebudayaan, dalam hal ini budaya Eropa. Dia menyebutkan bahwa warna emas menjadi simbol sesuatu yang agung (Gage, 1990: 518). Oleh karena itu, hal ini dapat dikatakan bahwa warna emas mendukung makna keindahan dan keagungan dari Lorelei. Hal itu bertujuan untuk menunjukkan ketinggian posisi Lorelei sebagai seorang individu. Sayangnya, posisi ini tetap menempatkan Lorelei sebagai sebuah objek yang diimpikan untuk dimiliki. Pada pembahasan selanjutnya, posisi yang dimiliki Lorelei ini terlihat bergerak dan dipengaruhi oleh relasi dengan tokoh tokoh yang mengelilinginya. 
Frasa "die Wellen verschlingen" (ombak menelan) pada kutipan bait ke enam juga dapat dihubungkan dengan peran perempuan sebagai sosok yang lain. Sementara itu, kata ombak yang identik dengan segala sesuatu berhubungan dengan laut. Lautan diumpamakan seperti perempuan karena sifatnya yang penuh marabahaya, penuh teka-teki, dan tidak mudah untuk dikuasai. Perempuan dijelmakan ke dalam bentuk pegunungan atau lautan. Hal ini dikarenakan sikapnya yang pasif dan dilihat sebagai mangsa yang dapat dikuasai (Beauvoir, 1956: 174175). Interpretasi frasa tersebut juga dapat dikaitkan dengan mitos femme fatale. Oleh karena itu, pada akhirnya, ombak menelan sang nakhoda. Frase femme fatale di sini adalah perempuan yang menggunakan daya tariknya. Dalam hal ini, suara merdu dan kecantikan ini pada hakikatnya bersifat mencelakakan (Beauvoir, 1956: 205).

Mitos femme fatale terlihat dengan jelas. Hal ini dikarenakan Lorelei menggunakan nyanyian yang dapat menghipnotis siapapun dan membawa ke dalam marabahaya. Daya tarik ini begitu memikat. Namun, hal ini justru mengandung sesuatu yang mencelakakan. Posisi Lorelei pada puisi Heine yang berada dalam masa romantik. Hal ini masih sangat kuat untuk menempatkannya sebagai objek yang diinginkan oleh laki-laki. Penggambaran atribut kecantikan, keperawanan, keindahan suara, dan hiasan dalam diri Lorelei mengafirmasi kualitas stereotip perempuan yang ideal dan diinginkan oleh laki-laki. Namun demikian, kecantikan dan keindahan ideal yang ada Lorelei ini tetap berakhir buruk bagi laki-laki yang menguatkan mitos femme fatale pada perempuan.

\section{Konstruksi Citra Fisik Perempuan dalam Loreley karya Dschinghis Khan}

Lirik yang berjudul Loreley karya Dschinghis Khan diciptakan pada tahun 1981. Lirik ini memiliki enam bait dan terdapat selipan sebuah refrain di setiap dua bait. Pada lirik ini, Dschinghis Khan menggunakan sudut pandang orang ketiga atau yang biasa disebut dengan Er-Erzähler ${ }^{3}$. Hal ini dikhususkan pada auktoriale Erzählperspektive karena pencerita mengetahui keseluruhan jalan cerita. Hal ini terlihat dari penyebutan orang ketiga pada lirik ini yang terdapat pada larik "Denn sie hat nur einen geliebt" (karena ia hanya mencintai seseorang). Lirik Dschinghis

\footnotetext{
${ }^{3}$ Sudut pandang Er-Erzähler terbagi menjadi tiga, yaitu auktoriale, personale, dan neutrale. Perspektif auktoriale disebut juga sebagai pencerita serba tahu karena ia paham keseluruhan jalan cerita serta memberikan komentar serta penjelasan. Perspektif personale berasal dari salah satu tokoh dan melihat jalannya cerita dari sudut pandang seorang tokoh dalam cerita. Sebaliknya, perspektif neutrale berada di luar garis cerita, artinya pencerita tidak masuk dalam cerita tersebut. Dia melihat jalannya cerita dari sudut pandang kamera. (Marquaß: 1997, 61)
} 
Khan ini tidak memiliki rima dan termasuk puisi bebas yang tidak terikat oleh aturan tertentu.

Penggunaan aliterasi juga dijumpai pada lirik ini. Salah satu contohnya adalah pada larik "Denn sie hat nur einen geliebt". Lirik ini memunculkan bunyi /n/, yang dipakai untuk menekankan makna kesetiaan Loreley kepada kekasihnya. Selain itu, pemakaian asonansi bunyi / $\mathrm{u} /$ pada larik "Und ihr Lied klang so sï $\beta$ " juga ditemukan. Penggunaan asonansi bunyi / $\mathrm{u} /$ disini seolah mengintensifkan makna betapa manisnya suara Loreley terdengar.

Pada Loreley, Dschinghis Khan menampilkan tokoh Loreley dengan banyak tokoh laki-laki yaitu "jeder", "einen", "der", dan , "er". Kata itu "jeder". Hal ini memiliki makna "setiap" yang merujuk kepada setiap laki-laki. Kata berikutnya, kata "einen" mempunyai arti sebagai "seorang (pria)". Kata "einen" sebenarnya merupakan kata yang direduksi dari frasa "einen (Mann)". Selanjutnya, kata "der" yang memiliki makna "laki-laki tersebut" mengacu pada laki-laki dalam larik sebelumnya. Hal ini secara khususnya adalah bahwa laki-laki yang dicintai oleh Loreley. Begitu pula dengan kata "er", kata ini juga memiliki arti "ia", yang masih mengacu kepada kedua larik sebelumnya. Penyebutan-penyebutan tersebut seluruhnya sama sekali tidak mengutarakan siapa sebenarnya identitas laki-laki yang sedang dibicarakan. Hal ini dapat dihubungkan dengan peran laki-laki sebagai Subjek. Hal ini dikarenakan untuk menjadi Subjek. Laki-laki tidak perlu menjelaskan siapa dirinya (Beauvoir, 1956: 14)

Selain itu, sajak tersebut menampilkan dua kalimat yang dapat dihubungkan dengan mitos penciptaan, yang -seperti pada puisi Heine-, yang menempatkan Loreley sebagai objek, yaitu "jeder wollt sie zur Frau" (setiap (pria), yang menginginkannya sebagai istri) dan "sie wird bald mein" (dia akan segera menjadi milikku). Dalam mitos penciptaan, Adam diciptakan dari tanah liat. Sementara itu, Hawa dari tulang rusuk laki-laki adalah fakta yang terus diulang dan dijadikan sebuah konsep politik seksual.

Dalam konteks ini, Hawa dihidupkan sebagai pasangan agar Adam tidak merasa kesepian. Kenyataan ini membuat laki-laki merasa sombong dan menganggap perempuan sebagai sebuah musibah yang menyenangkan (Beauvoir, 1956: 161). Peran laki-laki sebagai Subjek juga dapat dilihat pada kata "Krieg" (perang) dan "die Fischer" (para nelayan). Kedua kegiatan ini menekankan perilaku khas laki-laki di masa lampau seperti berburu, mencari ikan, dan berperang. Hal itu sekaligus menunjukkan keberadaan dirinya serta bagaimana dirinya memandang dunia (Beauvoir, 1956: 99). Berikutnya, pada kalimat "Und ein Prinz hörte auch von der schönen Loreley" (dan seorang pangeran juga mendengar kabar Loreley yang 
cantik), hal yang utama adalah untuk menegaskan posisi laki-laki sebagai Subjek. Sang Pangeran yang seolah mengejar Loreley memiliki relevansi dengan tokoh pahlawan, petualang, penyelamat, dan menjadikan perempuan sebagai hadiah yang patut diperebutkan (Beauvoir, 1956: 198-199).

Hal yang menarik dalam lirik Dschinghis Khan ini adanya penggambaran kesetian Loreley terhadap kekasihnya yang pergi berperang dan tidak kembali. Keberadaan Loreley di atas tebing untuk menunggu kekasihnya dengan penuh kesetiaan digambarkan dengan kalimat kalimat "Doch ihr Herz war nicht mehr frei" (namun hatinya tak lagi bebas). Hal ini menegaskan bahwa Loreley tidak mau membuka hati kepada siapapun, "Denn sie hat nur einen geliebt" (dia hanya mencintai satu laki-laki). Di satu sisi, kalimat-kalimat ini akan mengingatkan seseorang pada keterkaitannya dengan sejarah garis patrimoni.

Perempuan dimiliki laki-laki sehingga perempuan dituntut menunjukkan kesetiaan tanpa batas. Sebab, jika karena tidak, dia akan dianggap melakukan tindak kriminal (Beauvoir, 1956: 107). Sisi ini menempatkan Loreley dalam posisi dipaksa dalam kewajiban untuk setia. Namun, di sisi lain, jika hal ini dilihat dari tidak adanya indikasi diksi- diksi dalam puisi yang mengarah pada keharusan Loreley untuk setia, hal ini dapat diartikan bahwa ia melakukannya dengan hati dan keinginan sendiri. Posisi ini menjadikan Loreley menjadi subjek dalam tindakan tersebut. Subjektivitas yang kuat atas kegelisahan hati ini disebabkan kehilangan kekasih. Hal ini membuatnya bersikap dingin dan tidak merasa kasihan. Hal in i muncul dalam kutipan "Ihr hat keiner Leid getan", (ia, Loreley, sama sekali tidak menyesal) saat korbannya tenggelam akibat terbuai keindahan suara dan kecantikannya.

Penggambaran fisik dan kegiatan yang dilakukan Loreley masih tidak jauh berbeda dengan yang ada pada puisi Heine. Kegiatan utama yang dilakukannya adalah "kämmst" (menyisir). Hal ini dihubungkan dengan kegiatan bersolek untuk mempercantik diri. Perilaku ini juga berhubungan dengan kegiatan yang bersifat domestik dan berelevansi dengan maternitas yang memposisikan perempuan ke dalam suatu eksistensi yang dilaksanakan secara santai (Beauvoir, 1956: 94). Seperti halnya Heine, warna emas yang sangat lekat dengan Loreley juga ditampilkan untuk menunjukan keindahan, kemewahan dan keagungan. Namun, hal itu membawa pada kematian. Hal ini tergambar pada kalimat "Und wer hörte, wie sie sang, der verga $\beta$ dabei die Gefahr"(siapa yang mendengar, bagaimana dia bernyanyi, maka akan melupakan bahaya yang mengintai). Hal tersebut dihubungkan dengan ketertarikan laki-laki terhadap perempuan yang membawanya ke dalam sebuah musibah, yaitu kematian dan menguatkan mitos femme fatale. 
Sementara itu, laki-laki yang terjebak pesona perempuan akan diperalat nafsunya. Sebab, mereka tidak akan memiliki kekuatan untuk melakukan apapun. Dia membiarkan dirinya terperangkap menuju ke pengasingan. Hal ini terlihat jelas bahwa perempuan tidak hanya dipandang sebagai sosok yang penurut seperti yang biasa dikonstruksikan. Akan tetapi, hal ini juga dikonstruksikan sebagai sosok yang jahat (Beauvoir, 1956: 183). Yang terakhir, fakta ini muncul pada kata "Zauberei" (sihir). Kata ini dapat dihubungkan dengan mitos femme fatale. Hal ini disebabkan oleh kecantikan dan keindahan suara Loreley yang disiratkan sebagai sebuah sihir jahat yang sangat mematikan.

\section{Mitos Perempuan yang Berbahaya dalam Lore Lay karya Faun}

Lirik yang berjudul Lore Lay karya Faun ini mengambil puisi ciptaan Clemens Brentano, yang ditulis pada tahun 1802. Namun, dia menambahkan satu bait karangan mereka sendiri. Bait tersebut adalah sebagai berikut.

\section{Ich selbst muss drin vergehen \\ Und bin des Wartens müd \\ Denn keiner kann bestehen \\ Der meine Augen sieht}

(IV: 1-4)

Dalam bait itu, ada dua jenis sudut pandang yang dipakai, yaitu sudut pandang Er-Erzähler, khususnya auktoriale Perspektive dan Ich-Erzähler. Hal ini menunjukkan bahwa tokoh ich hanya berupa Sprecherinstanz. Selain itu, ada pula beberapa aliterasi. Salah satu contohnya adalah "Wohnt eine Zauberin" (tinggallah sesosok penyihir). Bunyi /n/ termasuk ke dalam suara melodius jenis liquid. Jenis ini dipakai untuk memaknai peran Lore Lay sebagai penyihir. Dalam bait itu, ada pula asonansi yang berupa bunyi /i/ pada "Und riß viel Herzen hin" (dan menghancurkan banyak hati). Hal ini digunakan untuk mengintensifkan makna karena terdapat banyak kehancuran hati karena Lore Lay. Penggunaan anafora juga dijumpai sebanyak tiga kali, yaitu pada kata "die" pada kutipan bait berikut.

Die Augen sanft und wilde

Die Wangen rot und weip

Die Worte still und milde

Anafora ${ }^{4}$ ini dimanfaatkan untuk memaknai hal-hal yang menjadi daya tarik Lore Lay. Hal-hal tersebut berupa matanya yang lembut dan liar, pipinya yang

\footnotetext{
${ }^{4}$ Anafora atau Anapher adalah pengulangan kata-kata yang sama pada suatu bait secara berurutan (Esser, 2007: 46)
} 
pucat dengan semburat rona merah, dan ketenangan serta kehalusan kata-katanya. Berikutnya adalah pemakaian enjambement5 pada kalimat "Zu Bacharach am Rheine Wohnt eine Zauberin". Kalimat ini memaknai seorang penyihir yang tinggal di daerah Bacharach. Ketiga kalimat tersebut juga berhubungan dengan mitos femme fatale. Kalimat "Die Augen sanft und wilde" (matanya lembut dan liar) ini dapat dianalogikan sebagai daya tarik yang dimiliki oleh Lore Lay yang memikat.

Berikutnya adalah kalimat "Die Wangen rot und wei $\beta$ ". Kombinasi warna merah dan putih ini menyimbolkan perasaan yang membara dan kemurnian. Di satu sisi, konotasi pipi merona mengacu pada perasaan malu-malu. Namun, di sisi lain, hal ini juga merupakan tanda dari ketertarikan seksual yang dipicu oleh adanya kehadiran orang yang diinginkan (Crozier, 2016). Daya tarik lainnya adalah suara yang terdapat pada larik "Die Worte still und milde". Hal ini seolah menambah daya tariknya karena nada suara biasanya menentukan karakter seseorang. Biasanya, nada tinggi ini mengekspresikan ketegangan dan kemarahan. Sebaliknya, nada rendah memiliki konotasi ketenangan atau sikap yang dingin. Tiga komponen daya tarik itu disebut sebagai "Zauberkreis" (lingkaran sihir). Makna Zauberkreis tersebut berhubungan dengan sihir. Sihir ada dikarenakan memang diciptakan untuk perempuan. Oleh karena itu, hal apapun yang terlihat alamiah pada perempuan akan dipandang sebagai penyihir (Beauvoir, 1956: 182).

Lirik ini juga ditemukan dalam dua jenis penokohan, yaitu Lore Lay dan die Männer (para laki-laki). Relasi antara keduanya terbagi ke dalam kedudukan Subjek dan Sang Lain. Tokoh laki-laki pada lirik ini tidak begitu banyak dideskripsikan. Konsep laki-laki sebagai Subjek juga terlihat dari larik "Der Männern rings umher" (para laki-laki di sekelilingnya). Keberadaan laki-laki di sekeliling Lore Lay secara tersirat dapat dikatakan bahwa mereka menginginkannya. Hal ini berhubungan dengan mitos penciptaan. Laki-laki mencari sosok perempuan sebagai seorang pelengkap hidup. Hal ini dipandang sebagai takdir yang harus dijalani oleh laki-laki yang berharap dapat memenuhi kekurangannya (Beauvoir, 1956: 161).

Konsep tersebut muncul dalam teks ini. Konsep perempuan sebagai Sang Lian terlihat pada "Zauberin" (penyihir). Namun, penyihir cenderung berhubungan dengan penggambaran mitos paling kuno dalam kisah yang mengisahkan perempuan sebagai tabib atau penyihir perempuan. Sihir memang tercipta untuk diri perempuan (Beauvoir, 1956: 182). Bahkan, banyak yang tidak segan untuk menuduh perempuan yang memiliki wajah cantik sebagai seorang penyihir

\footnotetext{
5 Enjambement berasal dari bahasa Prancis yang berarti Überschreitung atau pelanggaran. Penggunaannya dalam puisi berfungsi untuk menandai jeda sejenak pada antar larik (Esser, 2007: 47)
} 
(Beauvoir, 1956: 205). Kemudian, atribut feminitas perempuan juga ditemukan pada kata "schön" (cantik) dan "feine" (elok). Keduanya dapat dihubungkan dengan tuntutan laki-laki terhadap perempuan mengenai kecantikan. Kecantikan yang didambakan oleh laki-laki membuat tubuh perempuan memberikan kualifikasi objek yang lemah juga pasif (Beauvoir, 1956: 175).

Selain itu, ada kedudukan perempuan sebagai subjek yang terangkum pada kutipan bait ketiga. Pada kutipan bait tersebut, secara tersirat, ada beberapa frasa mengenai kedudukan perempuan sebagai Sang Lain. Secara khususnya, hal itu berhubungan dengan mitos fermme fatale. Frasa-frasa tersebut adalah "Die Augen sanft und wilde" yang berarti "Matanya lembut dan liar ". Sementara itu, frase "Die Wangen rot und wei $\beta$ " memiliki makna bahwa "Pipinya (merona) merah dan berwarna pucat". Fisik yang dimiliki Loreley digambarkan sebatas pada wajah, khususnya mata dan pipinya. Mata diilustrasikan sebagai pusat dari wajah manusia. Bahkan, William Shakespeare menyebut mata sebagai "jendela hati".

Secara spesifik, teks ini mengambarkan bahwa mata Lore Lay lembut sekaligus liar. Dua hal yang paradoks ini dapat dianalogikan sebagai daya tarik yang dimiliki oleh Lore Lay. Hal ini ditujukan agar memikat siapapun yang melihatnya. Daya tarik lainnya yang dimiliki oleh Lore Lay adalah semburat kemerahan pada pipinya yang pucat. Meskipun secara harfiah kata "wei $\beta$ " memiliki makna putih, dalam konteks ini, warna tersebut dapat dikatakan sebagai pucat. Kombinasi warna merah dan putih ini menyimbolkan perasaan yang membara dan kemurnian. Di satu sisi, konotasi pipi merona mengacu pada perasaan malu-malu, namun di sisi lain juga merupakan tanda dari ketertarikan seksual yang dipicu oleh adanya kehadiran orang yang diinginkan (Crozier, 2016)

Keterlibatan Lore Lay dalam larik "Ich selbst muss drin vergehen" dan "und bin des Wartens müd" (saya harus pergi ke sana sendiri, saya lelah menunggu) menunjukkan bahwa dia merupakan sosok eksisten yang mampu membuat satu keputusan dan tindakan. Tindakan ini didorong oleh keinginan bertemu dengan sang kekasih yang tidak pernah kembali. Satu sinyal subjektivitas yang tergambar pada lirik di tahun 2013. Namun, mitos fermme fatal juga masih ditemui atau intensitasnya cukup sering muncul. Misalnya, dua larik berikutnya yang berbunyi "denn keiner kann bestehen, der meine Augen sieht" (karena tidak ada yang dapat bertahan, saat melihat mataku) menjelaskan petaka yang dihadirkan oleh Lore Lay. Sehubungan dengan hal tersebut, daya tarik yang dimiliki oleh Lore Lay terletak pada kedua matanya. Hal ini membuat siapa saja yang menatapnya akan terbuai dan merasakan akibatnya. 


\section{SIMPULAN}

Hal utama yang hendak disampaikan oleh ketiga teks itu adalah konstruksi mengenai perempuan atau bagaimana perempuan direpresentasikan dari waktu ke waktu sepanjang sejarahnya. Konstruksi itu dapat berupa perempuan sebagai sesuatu yang harus dimiliki dan dikuasai, perempuan yang fisiknya menarik untuk laki-laki, dan perempuan yang berbahaya bagi laki-laki. Dari semua hal itu, hal utama yang disampaikan ketiga teks itu adalah mitos femme fatal yang kuat dalam pikiran masyarakat. Berdasarkan teori feminisme eksistensialis, hal yang didapatkan adalah bahwa mitos tersebut tidak terkonversi dengan adanya perubahan zaman sekalipun. Hal ini dapat dijumpai pada posisi subjek dalam beberapa bait. Namun, hal tersebut masih samar dan tidak terlihat karena kuatnya penempatan posisi objek untuk Lorelei. Hal yang dominan dalam peran dilakukan perempuan di dalam ketiga lirik tersebut juga sesuai dengan konstruksi masyarakat mengenai bagaimana seorang perempuan dilihat dan dikonstruksikan. Hal ini dapat dimungkinkan jika ada perubahan penggambaran Lorelai di masa selanjutnya.

\section{DAFTAR PUSTAKA}

Aryaguna, N.W.M. (2012). “Lorelei: Citra Perempuan dari Sudut Pandang Laki-laki dalam Tiga Puisi Masa Romantik karya Clemens Brentano, Otto Heinrich Graf von Loeben, dan Heinrich Heine". Skripsi, Universitas Indonesia

Beauvoir, S. (1956). The Second Sex. London: Lowe and Brydone and bound by A.W. Bain and Co

Bertens, K. (1987). Fenomenologi Eksistensial. Jakarta: PT Gramedia Pustaka Utama.

Crozier, W. R. (2016). “The Blush: Literary and Psychological Perspectives”, Journal for the Theory of Social Behaviour, 46,(4), 2016, 502-515, DOI: 10.1111/jtsb.12105

Dagun, S.M. (1990). Filsafat Eksistensialisme. Jakarta: Rineka Cipta.

Djajanegara, S. (2000). Kritik Sastra Feminis: Sebuah Pengantar. Jakarta: PT Gramedia Pustaka Utama

Djajanegara, S. (2010). Bahasa, Sastra, dan Wanita. Jakarta: Penaku

Diana, J. (2018). Citra Sosial Perempuan dalam Cerpen Kartini Karya Putu Wijaya: Tinjauan Kritik Sastra Feminis. Jurnal Pena Indonesia, Jurnal Bahasa Indonesia, Sastra, dan Pengajarannya, 4, (1), Maret 2018, 79-96 
Esser, R. (2007). Das große Arbeitsbuch Literaturunterricht - Lyrik, Epik, Dramatik. Verlag an der Ruhr

Gage, J. (1990). "Color in Western Art: an issue?", The Art Buletin Vol. 72, No 4. Desember 1990, hlm. 518-541

Gemberling, K. (2014). Femine Agendas: the Historical evolution of feminism as reflected in the content of American women magazines. The Elon Journal of Undergraduate Research in Communications, 2, (2), fall 2014, 51-58

Marquaß, R. (1997). Duden Abiturhilfen Erzählende Prosatexteanalysieren. Mannheim: Dudenverlag

Oelze, S.(2013). Der Rhein - Fluss der Romantik. Diakses dari https://www.dw.com/de/der-rhein-fluss-der-romantik/a-16966600 pada 6 Mei 2017.

Siwi Handayani, Christina Gadis Arivia. Haryatmoko. Robertus Robet. (2013). "Subjek yang Dikekang, Pengantar ke Pemikiran Julia Kristeva, Simone de Bauvoir, Michel Foucault, Jacques Lacan. Jakarta; Komunitas Salihara- Hivos.

Siswantoro. (2010). Metode Penelitian Sastra - Analisis Struktur Puisi. Yogyakarta: Pustaka Pelajar

Tseelon, E. (1995). The Little Mermaid: a icon women's in condotions partiarchy, and human condition of castration. The International Journal of Psychoanalysis, 76, (Pt 5), (5):1017-3 